\title{
Stock options could no longer be the carrot
}

Recruitment of top executives in US biotech companies could soon be hampered by new legislation requiring employee stock option compensation to be treated as an expense, a practice that's closer to most accounting standards in Europe. But biotech companies hope that a more lenient rule or delayed enforcement of the new ruling will help to ease the burden on small companies and retain a key incentive in recruiting experienced managers.

The new ruling was issued in mid-December by the Financial Accounting Standards Board (FASB), the designated standard-setting organization. Public company reporting should reflect the ruling for the first time by the third quarter of this year. Private companies, also beholden to FASB, are not expected to expense stock options until their annual accounting for the full year of 2005 .

FASB's requirement could have a detrimental effect on recruitment efforts for top talent, particularly by small biotechs. These companies are usually able to offer only limited salaries and bonuses, compared with their more sizeable counterparts, and require considerably more risk than larger companies and academia.

Requiring stock option expensing would "significantly alter the tools available to attract talent, affecting the smaller companies more," notes Ariella Haber, founder and CEO of The Agency, a recruitment firm specializing in biopharmaceutical executives located in Studio City, California. "Large companies can use other things to attract talent, smaller companies have fewer options."
Still, Haber argues that with biotech in a slump and a relatively flat stock market, today's candidates are less easily swayed by stock options offered by startups. "There have been a number of small companies that have offered very aggressive stock options, but they haven't done anything," says Haber. "The candidates have become very astute. They do a lot of research, like looking at filings and news."

Stock options remains an issue mostly for US firms. For European biotech companies, stock options have not played a significant role since the biotech bubble burst. An added deterrent is that stock options are already accounted for as expenses in most European countries. "Scientists definitely do expect stock options in the US," says cofounder and CFO Mirko Scherer of GPC Biotech, a Munichbased public oncology company with an office in the US. "In Europe, it became a currency that people liked, but after the bubble burst they became worthless.... That was the first experience with stock options in Europe. At least in the US, they had companies like Genentech as a positive example."

Cynthia Larbey, the managing director of London-based interim recruitment firm People in Health, specializing in life science, agrees: "Young companies' valuations are significantly underwater in Europe.... The exits and the stock options in some cases have not been worth the paper that they're written on. The preference is for higher base salaries or pension plans."

\section{B ox 1 Stock option expensing is not appropriate for biotech}

A survey of institutional investors conducted in November 2004 by BIO revealed remarkable indifference to the adoption of stock option expensing. Currently, institutional investors glean the stock option expense data from a footnote that is already required in filings by US public companies.

BIO's Ruffin is concerned that the FASB regulation will be unduly burdensome, particularly for small biotechs already laden with heavy accounting expenses associated with the recent implementation of Sarbanes Oxley regulations that came about in the wake of the Enron scandal to provide for stricter regulation of accounting disclosures.

And FASB regulations could affect a biotech company's bottom line. A public company that, for example, has given out moderate amounts of employee stock options, with around $\$ 10$ to $\$ 40$ million in expenses, can expect to see a hit to its earnings per share reducing them by one-third to one-half, according to a $\mathrm{BIO}$ analysis of some of its member companies' financials.

For biotechs not yet even breaking even, the reporting requirement makes even less sense. "To the extent that it adds to the noncash losses of a company that is already losing money for 10 to 15 years is not a material issue one way or the other," remarks one typical respondent to the BIO survey of institutional investors. "Since it adds work and provides no benefit, I would prefer to see things stay the same."

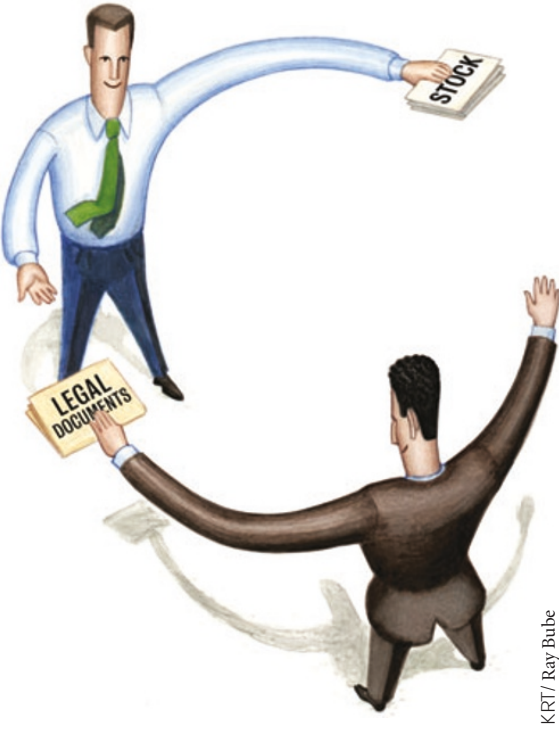

Stock options were until now, one of the main incentives to attract top managers into biotech companies. New FASB rules could change this.

There may be another way out for US biotech companies. Currently, legislation is in place that could conceivably contravene the FASB ruling. Last summer, the US House of Representatives passed the Stock Option Reform Act, which limits the companies required to report to those on the public markets for more than three years and with more than $\$ 25$ million in annual revenue. Even then, a company would only be required to report stock option expenses for its five largest option holders (Nat. Biotechnol. 22, 904-1065, 2004). An identical bill has been in committee in the Senate for over a year and could linger for longer.

Technology, biotech and venture capital industry associations have been lobbying fiercely to get this legislation passed, despite FASB's intentions. Even if industry associations are unsuccessful on that front, they are hoping to influence the Securities and Exchange Commission (SEC), which is responsible for enforcing FASB edicts (Box 1). Morrie Ruffin, the Biotechnology Industry Organization (BIO) vice president of business development and emerging companies in Washington, DC, comments: "We are hopeful that we can convince the SEC that special consideration needs to be given to small and mid-size technology companies either in how it is implemented or in the schedule."

Stacy Lawrence, San Francisco 